\title{
The Examination of a Milestone Recently Found in the Territory of Iuliopolis
}

\author{
Fatih ONUR*
}

In the $19^{\text {th }}$ volume of this journal, two new milestones found in the same spot ca. $12 \mathrm{~km}$ to the northwest of Iuliopolis were reported by F. Avcu. ${ }^{1}$ In her publication she managed to present only one of them, since the text of the second milestone was extremely difficult to read from the photos and it was impossible to examine the stone because of the travel restriction during the Covid-19 pandemic. ${ }^{2}$ In the early August 2020, I had an opportunity to examine and make a squeeze of this milestone (figs. 1-2), which has now been placed near the excavation area of Iuliopolis along with the other one. This investigation produced the following text:

H.: $165 \mathrm{~cm}$; Diam.: $55 \mathrm{~cm}$. Lh.: 5,5 cm.

$$
\begin{aligned}
& \text { B(ona) F(ortuna) }
\end{aligned}
$$

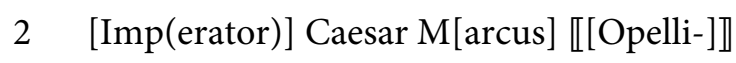

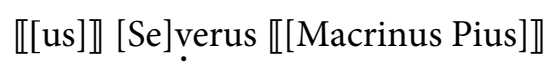

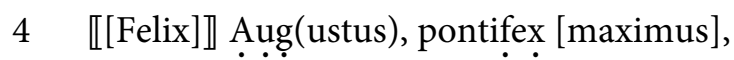

$$
\begin{aligned}
& \text { tribuniciae potesta(te) I, co(n)s(ul) [II] } \\
& 6 \text { [desig]natus, pater patriae, }
\end{aligned}
$$

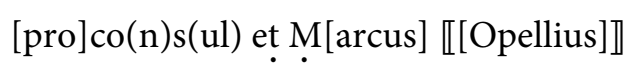

$$
\begin{aligned}
& 8 \text { [A]ntoninus 【[Diadumenianus }] \rrbracket \\
& \text { nobil[is] simus Caesar, filius } \\
& 10 \text { [ei]us, [p]rinc(eps) și.. A Iuliop[oli] } \\
& \text { VII } \quad \zeta^{\prime}
\end{aligned}
$$

With Good Fortune. Imperator Caesar Marcus Opellius Severus Macrinus Pius Felix Augustus, pontifex maximus, in the $1^{\text {st }}$ tribunician power, consul designate for the $2^{\text {nd }}$ time, father of the fatherland, proconsul, and Marcus Opellius Antoninus Diadumenianus, the most noble Caesar, his son, and princeps of his own. From Iuliopolis 7 (miles).

\footnotetext{
* Prof. Dr. Fatih Onur, Akdeniz University, Faculty of Letters, Dept. of Ancient Languages and Cultures, Campus 07058 Antalya (fatihonur@akdeniz.edu.tr; https://orcid.org/0000-0002-8568-0222).

I would like to thank Stephen Mitchell for improving the English of this paper and his observations. I also thank my parents, Yeter and Metin Onur, for helping me with the work in the field.

${ }^{1}$ Avcu 2020. The photos and other details of these milestones were passed to me by Mustafa Metin, an archaeologist working in the Museum of Anatolian Civilizations, Ankara, and in the excavations of Iuliopolis, of which I was the scientific advisor.

${ }^{2}$ Avcu 2020, 167 no. 2.
} 


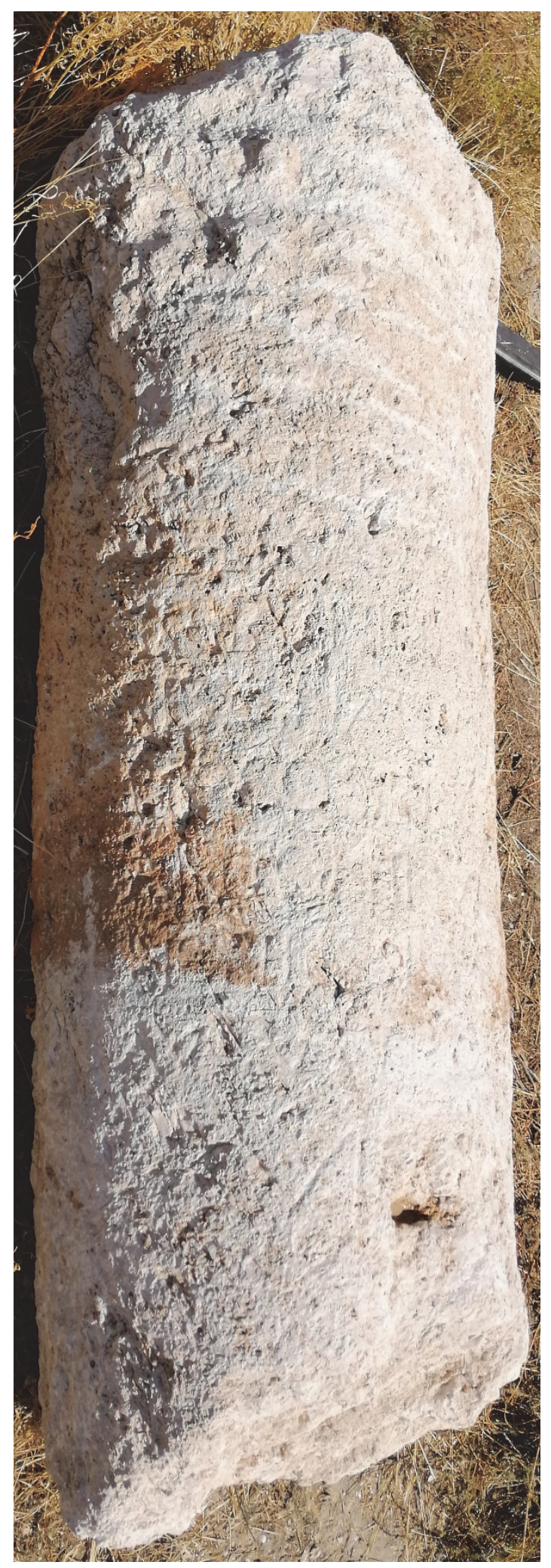

a) Left half

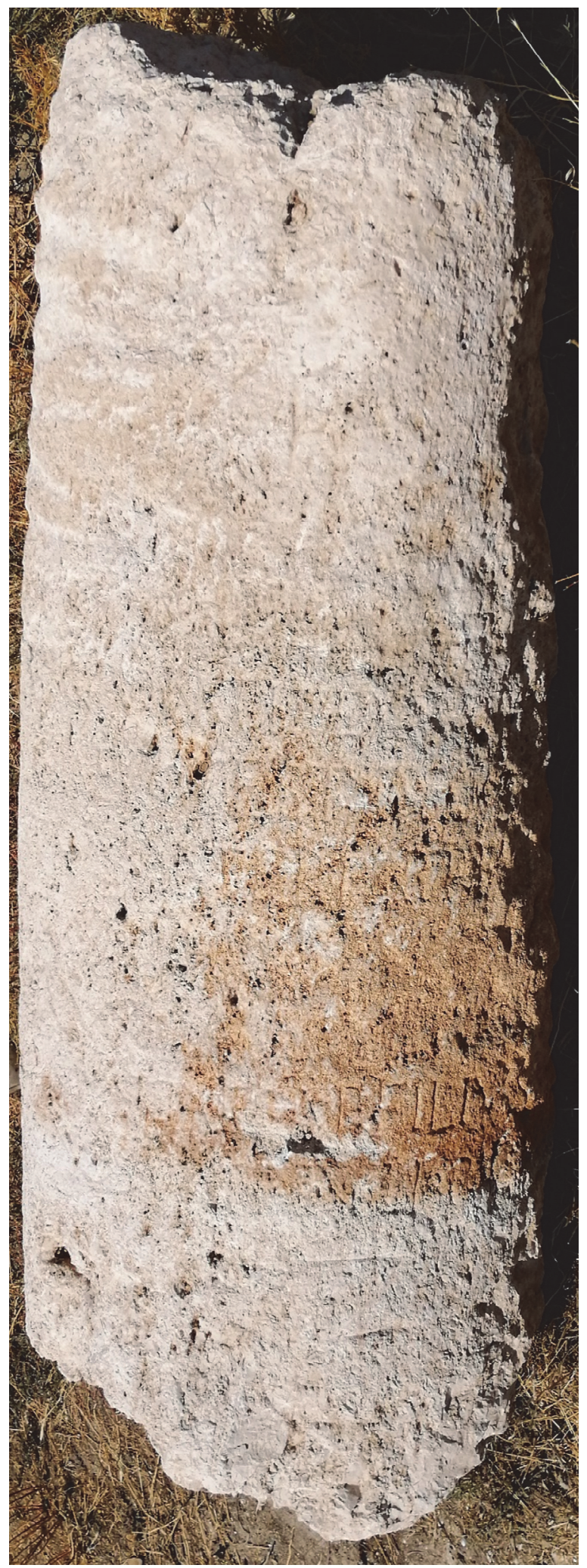

b) Right half

Fig. 1) The milestone 


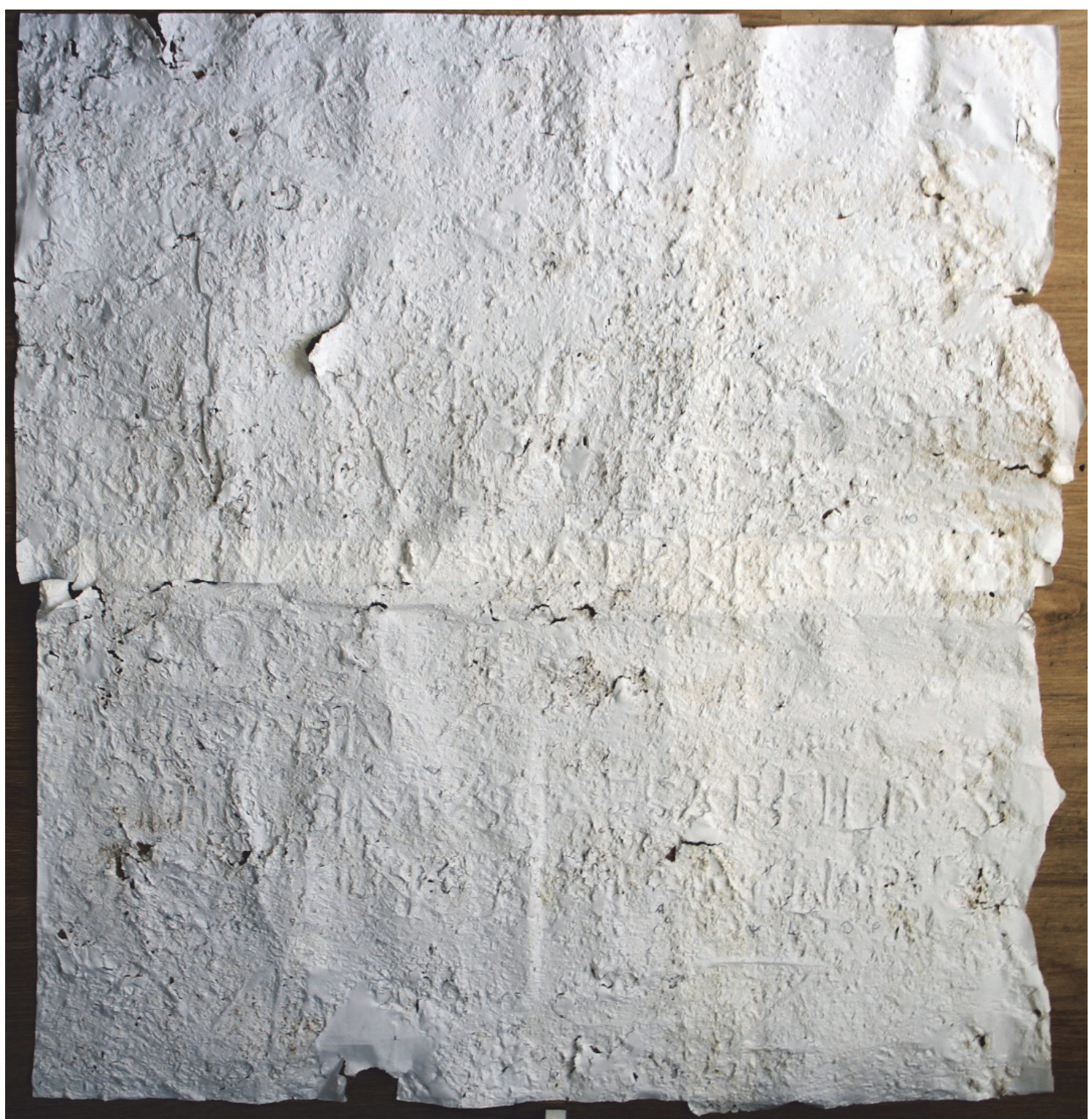

Fig. 2) The reverse image of the squeeze

Macrinus: trib. pot. I, Apr. 11-Dec. 9, 217; cos. II design., ca. Oct.-Dec. 31, 217; cos. II, 218; Diadumenianus: M. Opellius Antoninus Diadumenianus nobil[is]simus Caesar and princeps (Iuventutis), May 217; P. F. Augustus, May 218. ${ }^{3}$ Therefore, the date of the milestone is after October 217 (Macrinus, cos. II design.) and before May 218 (Diadumenianus, P. F. Augustus).

The appearance of Macrinus and Diadumenianus on the milestone is associated with the fact that Macrinus was in Caracalla's cortege as the prefect of his praetorian guard, and had Caracalla murdered before he became emperor himself. It is generally accepted that Caracalla's army marched along the so-called "Pilgrim's road", which was the main road leading through Nicaea, Iuliopolis and Ancyra. ${ }^{4}$

\footnotetext{
${ }^{3}$ Kienast - Eck - Heil 2017, 162-164.

${ }^{4}$ See the accounts in Drexler 1880; Magie 1950, 685 with n. 43; Levick 1967, 33; French 1981, 45; Johnston 1983; Onur 2014, 67; Avcu 2020, 168.
} 
Several milestones were erected on the road near Iuliopolis, on the Bithynian-Galatian provincial border, related to the Parthian campaigns of Caracalla's final years, and are shown in fig. 3:

1) [Caracalla] Marek 2000, 131, fn. 5; French 2013, 143, no. 91.

2) [Caracalla 10.xii.215- 9.xii.216] French 1981, 36, no. Çayırhan 1; French 2013, 144, no. 92.

3) [Caracalla 10.xii.215- 9.xii.216] Avcu 2020, 166 no. 1.

4) [Macrinus and Diadumenianus x.217 - v.218] Avcu 2020, 167 no. 2 and this contribution.

5) [Caracalla 10.xii.215 - 9.xii. 216] French 2013, 144-145, no. 93 (Çayırhan 2).

6) [Caracalla 10.xii.215 - 9.xii.216] French 2013, 145, no. 94 (Çayırhan 3).

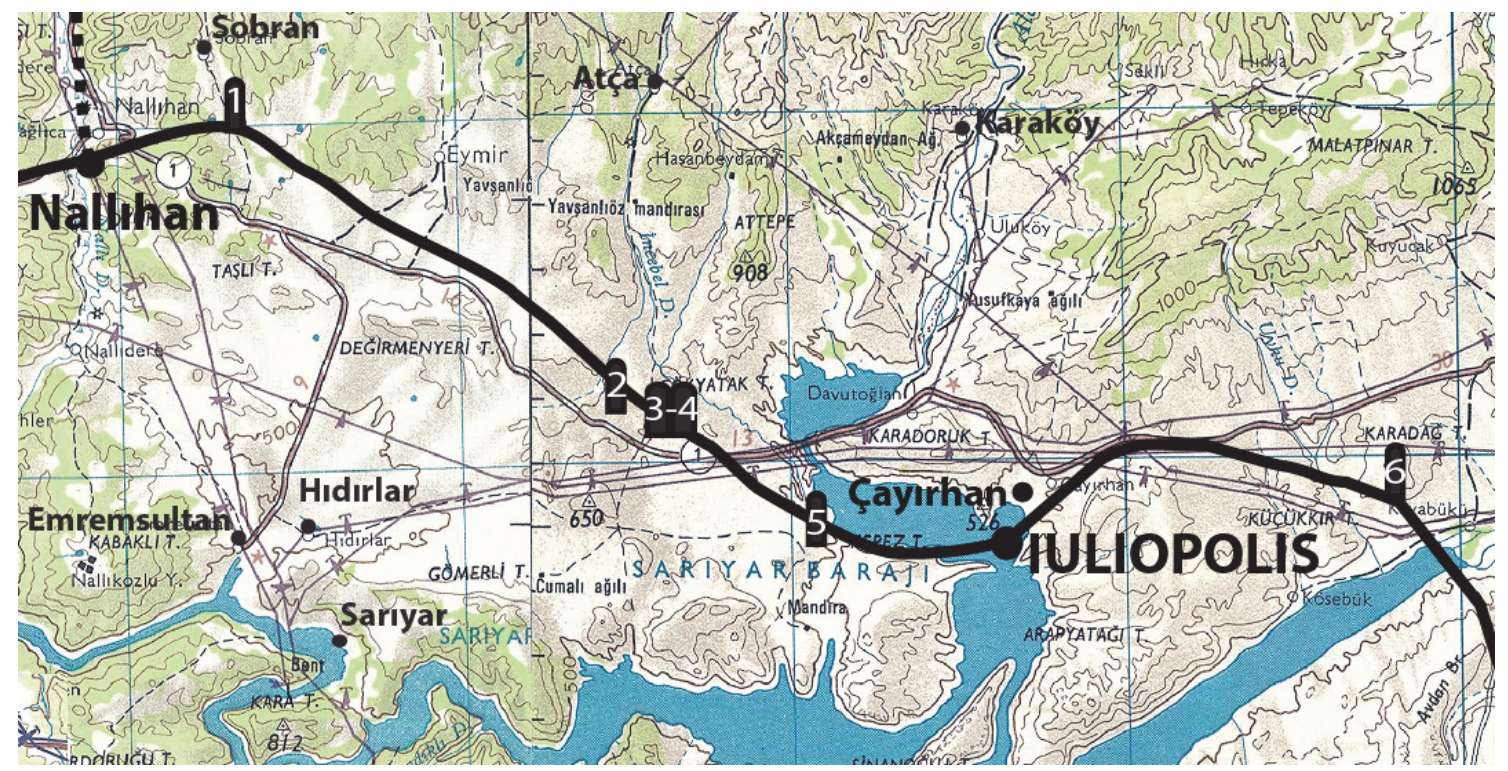

Fig. 3) The milestones around Iuliopolis (after HGK maps of 1:250.000)

Macrinus himself, together with Diadumenianus, also erected milestones on other sections of this road, ${ }^{5}$ although he remained in Antiochia (ad Orontem) and was never back in Rome.

It is interesting to note that a new milestone was put up at once to mark the change of régime from Caracalla to Macrinus. The Caracalla stone (3) is well preserved, perhaps because the column had been dismounted and the recently-cut inscription was put face down, when it was replaced by the stone for Macrinus (4), which is much more weathered. ${ }^{6}$ The names of Macrinus and Diadumenianus were subsequently erased as a result of damnatio memoriae. Ironically, Caracalla's name was untouched.

The distance of seven miles to Iuliopolis, on milestones 3 and 4 fits today's distance from findspot to Çayırhan. However, the distance number of milestone 2, restored by French as VIIII / $\Theta$

${ }^{5}$ French 2012, 264-265 no. 159, 266-267 no. 161 and 273-274 no. 165, all from Cappadocia; There are also other milestones from different routes in Asia Minor, see French 2012, 193-195 no. 108 [C] (Caesaria to Melitene); French 2014, 30-32 no. 15[B] and 35-36 no. 16[B]? (Mopsuestia - Anazarbus - Flaviopolis).

${ }^{6}$ Some of his attitudes towards to the memory of Caracalla can be read in a fragmentary chapter of Cassius Dio (79.19) reporting that Macrinus removed statues of Caracalla, although the latter did not officially suffer damnatio memoriae. 
(9 miles), ${ }^{7}$ does not correspond to the location of new milestones, which were only one mile away. Thus, French's restoration of the distance on Çayırhan 1 (no. 2 above) should be changed to VIII / $\mathrm{H}$ (8 miles).

\section{Bibliography}

Avcu 2020

F. Avcu, Two New Milestones from the Territory of Juliopolis, Gephyra 19, 2020, 165-172.

Drexler 1880

W. Drexler, Caracallas Zug nach dem Orient und der letzte Partherkrieg, Halle 1880.

French 1981

D. French, Roman Roads and Milestones of Asia Minor, Fasc. 1: Pilgrim's Road (BIAA Monograph. 3), Oxford 1981.

French 2012

D. French, Roman Roads and Milestones of Asia Minor Vol. 3: Milestones, Fasc. 3.3: Cappadocia (BIAA Electronic Monograph 3), London 2012.

French 2013 D. French, Roman Roads and Milestones of Asia Minor Vol. 3: Milestones, Fasc. 3.4: Pontus et Bithynia (with Northern Galatia) (BIAA Electronic Monograph 4), London 2013.

French 2014

D. French, Roman Roads and Milestones of Asia Minor Vol. 3: Milestones, Fasc. 3.7: Cilicia, Isauria et Lycaonia (and South-West Galatia) (BIAA Electronic Monograph 7), London 2014.

Johnston 1983

A. Johnston, Caracalla's path: The Numismatic Evidence, Historia $32,1983,58-76$.

Kienast - Eck - Heil 2017 D. Kienast - W. Eck - M. Heil, Römische Kaisertabelle: Grundzüge einer römischen Kaiserchronologie (6. Auflg.), Darmstadt 2017.

Levick 1967

B. Levick, Coins and Inscriptions of Colonia Comama, NC 7, 1967, 29-35.

Magie 1950

D. Magie, Roman Rule in Asia Minor, to the End of the Third Century After Christ, Princeton 1950.

Marek 2000

C. Marek, Die höchste, beste, grösste, allmächtige Gott, EA 32, 2000, 129-146.

Onur 2014

F. Onur, Epigraphic Research around Juliopolis I: A historical and Geographical Overview, Gephyra 11, 2014, 65-83.

${ }^{7}$ French 1981, 36, no. Çayırhan 1; French 2013, 144, no. 92. 


\section{Yakın Dönemde Iuliopolis Teritoryumunda Bulunan Bir Miltașının İncelenmesi}

Öz

F. Avcu bu derginin geçen sayısında Iuliopolis kentinin kuzeybatı teritoryumunda bulunmuş olan iki adet miltaşını sunmuştu. Bu miltaşlarından ikincisinin okuması fotoğraflardan yapılamamışı. Taş üzerinde yapılan inceleme neticesinde, miltaşının Macrinus Dönemi'nde dikildiği ve yazıtta caesar ve kendisinin princeps'i olarak Diadumenianus'un da yer aldığ anlaşılmıştır. Miltaşının tarihi Ekim 217 ve Mayıs 218 arasıdır.

Yazıtın çevirisi şöyledir:

İyi talihle! Imperator Caesar Marcus Opellius Severus Macrinus Pius Felix Augustus, en yüce rahip, halk hamiliğinin 1'incisinde, 2'inci konsüllü̈̆̈̈nü (yapmak üzere) seçilmiş, vatanın babası, proconsul ve Marcus Opellius Antoninus Diadumenianus, en soylu Caesar, onun oğlu ve kendisinin princeps'i. Iuliopolis'ten 7 (mil).

Anahtar sözcükler: Iuliopolis, Çayırhan, Bithynia, Galatia, Roman milestones, Macrinus, Diadumenianus.

\section{The Examination of a Milestone Recently Found in the Territory of Iuliopolis}

\section{Abstract}

F. Avcu presented two new milestones found in the northwest territory of Iuliopolis in the last volume of this journal. The text of the second of these milestones was not possible to read from the photos. An investigation of the stone concluded that the milestone was erected in the reign of Macrinus, mentioned together with caesar and his princeps Diadumenianus, sometime between October 217 and May 218.

Keywords: Iuliopolis, Çayırhan, Bithynia, Galatia, Roma Dönemi miltaşları, Macrinus, Diadumenianus. 